\begin{tabular}{lll}
\hline & Yönetim, Ekonomi, Edebiyat, & JOMELIPS - Journal of \\
Review Article & İslami ve Politik Bilimler & Management Economics Literature \\
Araştırma Makalesi & Dergisi,3(1): 44-69, & Islamic and Political Sciences \\
DOI: 10.24013/jomelips.414626 & 30 Haziran/June, 2018 & e-ISSN :2547-9512 \\
\hline
\end{tabular}

\title{
İbni Haldun'un İktisadi Kuramı: Devletin Ekonomi Üzerindeki Rolü ve Fonksiyonları
}

\author{
Zafer Demir ${ }^{1 *}$ \\ ${ }^{1}$ Sabahattin Zaim Üniversitesi- İslam Ekonomisi ve Uluslararası Finans Doktora Programı Öğrencisi
}

\section{ÖZ}

14.yüzyl'da bilimsel metodoloji ile kaleme alınan Mukaddime, İbni Haldun'un teorik alt yapısı ve pratik gözlemlerini dengeli şekilde bir araya getirdiği başyapıtıdır. Devletlerin refahı ve çöküşünü; çevresel, sosyal, ekonomik, politik ve tarihsel faktörlerin bir araya geldiği dinamik bir çerçevede tahlil eder. Kurucusu olduğu 'Umran' ilmi ile toplum refahını esas alan arz-talep, fiyat-ücret, emek-değer, üretim-tüketim ve tüm ekonomik sistemin murakabesini yapan devlet tanımıyla bütünsel bir model ortaya koymuştur. Devleti düzenleyici ve denetleyici rolü ile iktisadi hayatın önemli bir unsuru olarak işaret etmiș. Gelişmiş bir toplum ve istikrarlı refah için devletin üstlenmesi gereken rolleri örneklerle tarif etmiştir.

Anahtar Kelimeler: İbni Haldun, Mukaddime, İslami İktisat, Asabiyet Teorisi, Umran İlmi

\section{The Economic Theory of Ibni Khaldun: The Role and Functions of State in Economy}

\begin{abstract}
The Muqaddimah, which was taken with scientific methodology in the 14th century, is the masterpiece that brings together the theoretical background and practical observations of Ibni Haldun in a balanced way. Prosperity and collapse of the states; environmental, social, economic, political, and historical factors in a dynamic framework. The founder of 'Umran' has put forward a holistic model which describes the state which is the subject of the social welfare based supply-demand, price-wage, labour-value, production-consumption and the whole economic system. He pointed to the state as a regulatory and supervisory role and an important element of economic life. He described the roles that the state should undertake to exemplify an advanced society and stable prosperity.


Key Words: Ibn Khaldun, Muqaddimah, İslamic Economics, Asabiyat Theory, Umran Science

\section{GİRIŞ}

Batı Medeniyeti, tarihi kendi perspektifinden tanımlamış ve tasnif etmiştir. Zamanı ve çağları kendi yükseliş ve çöküş dönemlerine göre tarif etmiş olsa da İslam Medeniyetinin tarihsel tecrübesi ve gelişimi Batının tarihsel değişimi ile paralel olmamıştır. Batı Roma'nın yıkılışı ile derin bir sessizlik ve karanlık döneme giren Batı; bilim, sanat, fikir ve edebiyatta da yaklaşık on asırlık bir kayıp dönem yaşamıştır. Batı Medeniyetinin karanlık çağ diye tarif ettiği orta çağ dönemi İslam Medeniyeti için her alanda yükselmenin ve bilginin altın çağı olarak yaşanmıştır. İslam Medeniyetinin aydınlık ve yükselme çă̆ı, evrensel olarak değer ve birçok alanda önemli eserin üretildiği verimli bir dönemdir. $\mathrm{Bu}$ dönemde yetişen ve eserler bırakan çok sayıdaki İslam âlimi arasında son dönem temsilcilerinden birisi de İbni Haldun'dur. İbni Haldun (1332-1406) İslam coğrafyasının siyasi bunalımlar yaşamaya başladığ bir dönemde siyasetçi ve ilim adamı kimliği arasında geçen bir yaşam sürmüştür. Kâtiplik, vezirlik, sadrazamlık, elçilik, gibi değişik devlet görevleri ile kadılık, müderrislik, seyyahlık gibi ilmi görevlerde de bulunmuştur. Döneminin zorlu şartlarında kısa bir süre içerisinde çok sayıda devlet idaresi görevinde bulunmuş, farklı topluluklara tanıklık etmiş ve yakinen gözlemleme firsatı bulmuştur. Sahip olduğu teorik bilgi ile tecrübe ettiği uygulamaları sentezleyerek önemli görüşler ortaya koymuştur. Kuramları batıda ve doğuda birçok bilimin doğuşuna ve gelişimine öncülük etmiştir.

İbni Haldun'un başyapıtı olan Mukaddime asırlar geçtikçe bilimsel kıymetini ve değerini koruyan çok yönlü ve bilimsel metodoloji ile hazırlanmış bir eserdir. İslam Medeniyetinin normları ile beslenen, uygulama imkânı bulmuş ve tecrübe edilmiş gözlemlere dayalı, geniş bir coğrafyada hazırlanan ve çeşitlilikten beslenen bir eserdir. Çalışmamızda Mukaddime kitabı temel alınarak İslam bilgininin iktisadi görüşleri ve ekonomik modeli ile özelde devletin ekonomi üzerindeki rolü ve fonksiyonlarının ne şekilde olacağına dair iktisadi devlet modelini ortaya koymaya çalışacağız. Kendisinden asırlar sonra gelen modern iktisatçılara ilham ve bilgi kaynağı olan İbni Haldun'un ortaya koyduğu iktisadi görüşlerin çerçevesini çizeceğiz. Kuramlarının günümüz iktisadi problemlerin çözümünde 
etkin bir çözüm reçetesi olabileceği inancı ile modern iktisadi sorunlara yönelik sunulan modelin getireceği çözüm ve çıkış yollarını arayacağız.

\section{1. İbni Haldun'dun Bilimsel Metodolojisi}

İbni Haldun 14. Yüzyılda İslam Medeniyetinin ilmi ve fikri olgunluğa çıtı̆̆ı, siyasi ve politik istikrarsızlıkların yeni baş göstermeye başladığı bir dönemde yaşamıştır. Eğitim için İspanya, Fas, Tunus ve Mısır'a gitmiştir. Asil bir ailenin çocuğu olarak dünyaya gelmiş, tanınmış ilim adamlarından fıkıh, hadis, tefsir, mantık, matematik, fen bilimleri ve dil bilimleri dersleri almıştır. (Tekin, 2015) Eğitimini sadece İslami kaynaklardan değil batılı kaynaklara da ulaşarak, zamanın genel ilmi bilgilerine de sahip olmuştur. Sağlam bir eğitim temeli ile fikri alt yapısı oluşan düşünce adamı, daha sonra devletin değişik kademe ve farklı bölgelerde görev almıştır. Kâtiplik, elçilik, kadılık, vezirlik, müderrislik ve seyyahlık yapan İbni Haldun; adil ve tarafsız karakteri sebebiyle defalarca görevden alınıp hapis ve sürgün hayatı yaşamış bir fikir adamıdır. Sahip olduğu adalet inancı ve objektif kalabilme becerisi, olaylara ve zamana bakışında kendisini her zaman göstermiştir. Başyapıtı Mukaddime eserinde de gözlemlerini objektif bir bakış açısıyla, kimsenin etki ve tesirinde kalmadan, özgün bir dil ve yaklaşımla ortaya koymuştur. İbni Haldun’un aldığ1 derin teorik eğitim ve uygulayıcı olarak devletin birçok kademesinde görev alması ayakları yere sağlam basan ve tecrübe edilmiş bir model yapısını kurmuştur. Çok farklı konum ve bölgelerde aldığı görevler ile farklı toplumsal grupların tepkilerini gözlemleme firsatını yakalayarak tespitlerinin çok yönlü ve farklı açılardan değerlendirme firsatını yakaladığı söylenebilir. Bedevi toplumlara seyahat etmek suretiyle yerinde gözlemlemiş, ilk elden tarif ve tasnif etme firsatı yakalamıştır. Özetle hem teorisyen hem de uygulamacı sıfatıyla hâkim olduğu bilgi ve uygulamaları doğru bir şekilde yorumlamış ve özgün teorilerini ortaya koymuştur.

Mukaddime'nin başyapıt olarak kabul edilmesi ve üzerinden yedi asrın geçmesine karşın kuramlarının günümüz için 1şık tutabileceği inancının altında yatan nedenlerden birisi de eserin bilimsel metodoloji ile kaleme alınan ilk eser olduğu görüşüdür. (Beik \& Arsyianti, 2006) Toplumların yaşayış biçimlerine, tarihsel felsefenin olgunlaşmasına ve ekonomik tahlillerinde bu bilimsel yöntem ile nesnel bir metotla topluma, olayları ve gelişmeleri 
doğru bir şekilde tarif edebilmiş, tanımlayarak onları sınıflandırmış ve yalnız akıl nazarı ile değil düşence dünyasını şekillendiren hikmet ve irfan perspektifi ile yaklaşmıştır. Çağdaş ifade ile ampirik yöntem olarak kabul edilen bilgi ve uygulamanın tecrübe ile analiz edildiği bir tahlil yaklaşımı benimsenmiştir.

Batılı düşünce adamlarından ayrıldığı bu noktada akıl ve hikmeti aynı potada eriterek bir kuram ortaya koymuştur. Tahlillerinde ve tespitlerinde hangi yöntemleri kullandığ1 sorusunun cevabına gelince:

- Tarihsel Tahlil Yaklaşımı: Tarihsel olayların toplumlar üzerindeki etkisinin sadece politik ve siyasal alanda olmayıp ekonomik düzeyde gelişim ve değişimlere de etkisi olduğunu tarihsel olaylar ile birlikte izah edebilmiştir. Devletler ve iktidar dönemleri değiştikçe toplumların da dönüşüm ve gelişim yaşadığ dinamik bir değişim yaklaşımı ile tarif edilmiştir. Tarihsel süreçte toplumların ve ekonomik sistemlerinin dinamik bir yapıda olduğunu örnekler ile betimlemiştir. Devletlerin yükseliş ve çöküş döngüsü kuramında tarihsel olarak yükseliş ve olgunluk dönemlerinde güçlü ve canlı ekonomik hayatlarına dikkat çekmiş, ekonomik sistemin bozulduğu ve krize girdiği zaman dilimlerinde ekonomik hayatın çöküş ve durgunluk dönemlerine girdiğini izah etmiştir. Ekonomik vaziyetin hem sebep hem sonuç olarak belirleyici ve gösterge olarak tarihsel akışa göre değişim gösterdiğini gözlemlemiştir. Ekonomik sistemin bütün devlet organizasyonu içerisinde değiştiğini ve etkilendiğini tarihsel örnekler ile açıklamıştır. İbni Haldun'un Umran tarifinde kırsal yaşamı ifade eden bedevilik ile şehir yaşamı birlikte alınır. Bedevilik değişimin ilk aşaması olarak ele alınır şehir ve kırsal birlikte bir sosyal değişim içerisinde farklı aşamalardan geçer. (Meriç, 1974)

- Çevresel Tahlil Yaklaşımı: Mukaddime eserinin birinci bölümünde ekolojik ortamın, bireylerin ve toplumun üzerindeki etkilerini örnekleme ile açıklamıştır. Asırlar boyunca çevresel değişimlerin insan toplumları üzerindeki etkisinin ekonomik yaşamı da doğrudan etkileyen bir etken olarak görüldüğünü fark etmiştir. İklimler ve coğrafi koşulları, toplumların ekonomik düzen ve sistemleri hakkında belirleyici bir unsur olarak göstermiştir. Dünya iklimlerini tasvir ederken kuzey ve güneyin sert ve uygun olmayan 
koşulları karşısında yeryüzünün orta kısmının ekonomik hayat için en elverişli koşulların bulunduğunu aşağıdaki sözleriyle Mukaddimede açıklar.

"Zanaat ve sanatlar, güzel yapllar ve giyimler, yiyecek maddeleri ve meyvelerle hayvanlar, yeryüzünün ortasindaki bu iklimde yetişen bütün şeyler en mutedil ve uygun özellikleri kendisinde toplamışlardır."

İklimlerin, insanların ve toplumların üzerindeki etkilerini çok değişik örnekler ile tasvir etmiş, kavimlerde ve bireylerin ahlaki gelişimlerinde iklimin etkisi üzerine derin analizlere yer vermişsir. İklimin çevre ve toplumlar üzerindeki etkisine önemli bir yer ayıran düşünür, eserinde iklimin müsait ve uygun olduğu coğrafi bölgelerin gelişmişlik ve ekonomik canlılık açısından sahip olduğu mertebeyi örnekler ile açıklamıştır. (Ziya \& Fahri, 1940) İklimin ve istihsalin müsait olduğu coğrafi bölgelere nüfus hareketlerinin de çok olduğu ve nüfus ile toplumsal gelişimin beslendiği savını ileri sürmüştür. Ülkenin milli gelirinin artması ve yükselmesi için şehirleşmenin ve büyük nüfuslu şehirlerin artışının önemine değinmiş ve vurgulamıştır.

- Sosyolojik Tahlil Yaklaşımı: Sosyal çevre ve davranışların ekonomik karar ve davranışlara doğrudan etkilerini gözlemlemiş ve analiz etmiştir. Sosyolojinin babası olarak anılmasını sağlayan Umran İlmi ve Asabiyet Teorisi ile toplumun ekonomik yaşamı ve hareketlerini bir bütün olarak ele almıștır. Mukaddime eserinde toplumsal olayların ekonomik faaliyetlere tesiri ve ekonomik vaziyetin toplumsal gelişmelere etkisi iki yönlü olarak irdelenmiştir. (Al-Leheabi, Bahjat, \& Ramchahi, 2013) Sosyolojinin ekonomi üzerindeki etkisi ve etkileşimi her zaman göz önünde bulundurulmuştur. Toplumların gelişmişliği ve bilgi düzeyi ile ekonomik gelişmişlik arasında doğrudan ilişkiyi tespit etmiş ve vurgulamıştır. Gelişmiş şehir topluluklarında sanat ve zanaatların da gelişmiş ve ileri seviyede olduğunu gözlemleyerek bilimsel gelişmenin ve mesleklerin ileri şehir topluluklarında mümkün olacağı tezini savunmuştur. (Ahmad, 2003) Geniş bir coğrafyada gözlemlediği bedevi topluluklarının benzer ekonomik davranış ve faaliyetlerinin bulunduğunu işaret etmiştir. Şehir yaşamında ise kırsal yaşamın aksine sosyal yapının ekonomik yapıda farklılaşma ve ekonomik davranışların nasıl çeşitlilik göstereceğini örnekler ile açıklamıştır. 
- Organizmacı Yaklaşım: $\mathrm{Bu}$ yaklaşım toplumların ve sistemlerin canlı bir organizma gibi gelişim ve değişim gösterdiği fikrine dayanmaktadır. Farabi ve İbni Haldun benzer bir yaklaşımla devleti ve toplumları organizmaya benzetmiş ve betimlemiştir. (Yıldız, 2010) Farabi, devleti ve toplumu örgütsel bir vücut olarak ahenk ve organların hiyerarşi içinde çalıştığı bir yapı şeklinde tasvir etmiştir. İbni Haldun ise devletlerin ve sistemlerin canlı yapıda gelişen, değișen ve ortadan kaybolan organik sistemler olarak tanımlamıştır.

İbni Haldun bilimsel yaklaşımlarına ilave sahip olduğu gözlem ve objektif muhakeme yeteneği ile betimleme, tanımlama ve tarif etme noktasında eşsiz bir başarı yakalamıştır. İzlediği yöntem, tümevarım şeklinde gözlemlerini ve tahlillerini bir bütün olarak kuram haline getirerek sorunun çözümüne yönelik tez geliştirmiştir.

\section{2. İbni Haldun'un Ekonomik Modeli ve Kuramlart}

Mukaddime eserinde ortaya konulan ekonomik çıkarımların İslami iktisadının asli kaynakları olana Kur'an ve hadis bilgisini esas alındığını, eserin bölümlerinde ve cüzlerin içerisinde görebilirsiniz. Ekonomik modelin temelini oluşturan insanın yaratılış gayesi, üretme ve kazanma ihtiyacı ve ekonomik kararları her daim İslami ilkelere uyumlu olması şartı eserin her satırında aranmış ve sorgulanmıştır. Genel bir bakışla, ortaya konulan ekonomik modelin esas aldığı kaynağı ve tekâmül eden bilgi birikimi ile İslami İktisat Modeli örneği kapsamında değerlendirilmesi yanlış olmayacaktır.

\subsection{Sosyal Refah Kuramı}

İbni Haldun'un sosyo-ekonomik modelinde eserinin çatısını oluşturan Asabiyet yaklaşımı merkez kuramını üstlenmektedir. Dayanışma ve bağlılık şeklinde tarif edilebilecek yaklaşım, milletlerin ve devletlerin bir gaye etrafında karşılıklı yardımlaşma ve bağımlılık ilkesine dayanmaktadır. Bu dayanışma ekonomik hayatta uzmanlaşma, iş bölümü ve ekonomik çeşitlilik varsayımlarını beraberinde getirmiştir. (Chapra, 2014) Toplumsal refahın gelişimi ve istikrarlı bir şekilde temini ile şehrin gelişmişlik düzeyinin doğrudan ilişkisini tespit etmiştir. Eserindeki Mısır, Kahire ve Endülüs örneklerinde bir şehir gelişmişlik düzeyi ne kadar yüksek ise ekonomik refahında aynı oranda ilişkili olduğunu ortaya koymuştur. Üretim ve ticaretin çoğalması emeğin artışını beraberinde getirecek, 
emek artışı üretimi artırarak ihtiyacın üzerinde gerçekleşen üretim ve gelir toplumların refahı için gereken servetin kazanılmasını sağlayacaktır.

"Bir şehir, umran itibariyle ne ölçüde ileri ve mükemmel olursa, refahtaki vaziyeti itibariyle o şehir halkının durumu, onun aşağısındaki şehir halkının haline göre o nispette ileri olur." Mukaddime 2.Cilt:766 Sf.

Ekonomik refahın oluşması için ekonomik hayatta çeşitliliğin ve canlılığın gerekli şart olduğunu kabul etmiştir. Şehirde gelir ve gider ne oranda yüksek olursa üretilen değer, servet ve kalkınma o düzeyde yüksek olur şeklinde yorumlamıştır. Üretilen gelirin harcamaya dönmesiyle giderlerin de aynı oranda gerçekleşeceğini, gelir gider dengesinde gelirde yaşanacak artışın harcamaları da aynı oranda artıracağını bu ekonomik genişlemenin ise refahı yükselteceğini yorumlamıştır. Günümüz ekonomilerinde de piyasalarda görülen büyüme ve canlılık ekonominin sağlıklı olduğuna dair bir gösterge kabul edilmektedir. Ekonomik daralma ve durgunluk yaşayan ekonomiler beraberinde işsizlik, milli gelir düşüşü ve devlet bütçelerinde açıklara sebebiyet vermektedir.

İbni Haldun ekonomik olarak refah içerisindeki şehir ve toplulukların cazibe merkezi olması hem az gelişmiş şehirlerden toplulukların hem de ihtiyaç sahibi olan fakir halkların bu şehirlere göç etmesini sağladığını ifade etmiştir. Gelişmiş şehirlerde servet fazlası olduğu için ihtiyaç sahipleri ve muhtaçlara daha çok yardım edileceği ve refahın toplumun tüm katmanlarına yayılacağını iddia etmiştir.

"Insanlarin cemiyetler halinde yaşayarak imar ettikleri yerlerde hayat seviyesinin yüksekliği ve düşüklüğ̈̈, nimet ve servetin azlĭ̆l ve çoklŭ̆u ülkelerin mamurluğuna, başka söyleyişle, istihsalin azlı̆̆ına ve çokluğuna tabidir." Mukaddime 2.Cilt:769 Sf.

Toplum refahının ekonomik hayatın canlı ve üretim gücü ile ilişkisini, ülkede görülen verimli üretim kapasitesi ve emeğin sonucunda yükselen servetin o topluma refah getireceği görüşü ile desteklemiştir. Kırsal yaşamın ekonomik modelinin ancak kendine yetebilen bir üretim modeline sahipken şehirlerde uzmanlaşmış ve iş bölümü yapılmış organizma şeklinde çalışan bir ekosistem üretim ve tüketimin dengeli bir şekilde geliştiği, gelişimin şehri ve refahı artırdığı bir döngü şeklinde genişlediğini ifade etmiştir.

Sosyal refah kavramı Mukaddime eserinin değişik bölümlerine serpiştirilmiş ve farklı detaylar ile bir bütünlük içerisinde modellenmiş bir ideali oluşturur. Üretim ve ticaretin büyümesiyle birlikte toplumların servet birikiminin artacağını, bolluk ve zenginliğin ise 
sosyal refahın kaynağı olduğu vurgulanmıştır. Devletin ise canlı ve zengin ekonomik sisteme paralel olarak gelirlerini artırabileceği öngörüsünde bulunulmuştur.

"Bunun bir sonucu olarak o nispette refah derecesi yükselir. Bu yolla ekonomi gittikçe ilerleyip geçim genişler, zenginlik artar. Pazar'da alışverişin çoğalmasıyla da devletin geliri o oranda fazlalaşır, gücü artar." Mukaddime 2.Cilt:774 Sf.

Güçlü ve gelirleri yeterli bir devlet modelinde ülkenin ekonomisinin ve üretiminin önemi vurgulanmıştır. Şehir toplumlarında ve ekonomik pazarlarda yaşanacak bozulma doğrudan devletin gelirlerini azaltacaktır. Küçülen veya nüfusu daralan șehirlerde ekonomik canlılığın ve gelirin azalarak ekosistemin bozulduğunu örnekler ile bu tezinde açıklamıştır.

\subsection{Arz, Talep ve Fiyat Kurami}

Fiyat: Mukaddime eserinde, fiyatların nasıl oluştuğu ve şehirlerdeki değişiminin fiyatlara nasıl etki ettiğini açıklanmıştır. Modern iktisat teorisinde arz ve talebin fiyatı oluşturduğu tezini asırlar önce İbni Haldun örnekleme yoluyla anlatmış, fiyat oluşumunu malların arzı ve talebi arasındaki ilişkiden doğduğunu tespit etmiştir.

"Bir şehrin nüfusu çoğalırsa, yiyecek maddeleri ve buna benzer olan hayat için gerekli maddeler ucuzlar, katıkllk, meyve ve buna benzer olan nesnelerin fiyatı yükselir. Bir şehrin mamurluğu azalarak nüfusu eksilirse bunun tersine olarak, yaşamak için zaruri olan maddelerin fiyatları yükselir ikinci derecedeki ihtiyaçlardan olan ve rahat hayat için gereken nesnelerin fiyatları ucuzlar." Mukaddime 2.Cilt:769 Sf.

Yukarıda tahlil edilen örnekte nüfus artışı ile birlikte bireylerin ve üreticilerin ihtiyaç duydukları ürünlerin üretimi için verdikleri emeğin bir bütün olarak yüksek nüfuslarda temel ihtiyaç ürünlerinin arzını artıracağından fiyatların düşüşüne neden olacağı tespiti yapılmaktadır. Nüfus ve ekonomik davranışlar arzı etkileyerek azalan arz veya ürün miktarı doğrudan fiyatların artış veya azalışlarına sebebiyet verebilmektedir. Temel ihtiyaç maddeleri dışındaki ikinci derece ihtiyaç şeklinde tarif edilen tali ihtiyaçların refah arttıkça tercih sebebi olarak daha yoğun bir talep ile karşı karşıya kalacağını ve yükselen talebin fiyat artışlarına bağlı olarak mal kıtlığını doğuracağını tahlil etmiştir.

Talebin gayrimenkullerin fiyatlarına olan etkisini de aynı şekilde izah etmiştir. Toplumların ve devletlerin buhran dönemlerinde bireylerin sahip olduğu toprak ve gayrimenkullere ilginin yok olması veya azalması sonucu mülklerin fiyatları düşer ve ucuz 
fiyattan satılabilir. Ortam düzelip şehirler güvene kavuştuğunda ise rağbeti artan, yükselen talebin arzı sabit olan gayrimenkullerin değerinde artış ve fiyatında yükselme ile etki eder.

Fiyatın pazarda arz ve talebin dengede oluşacağı fikrini savunan düşünür, eserinde talebin ve arzın hangi şartlarda değişiklik göstereceğini veya farklılaşacağını sosyal unsurların içinde olduğu dinamik bir yapıda ele alır. Devletin fiyata müdahalesi, üretici ve tüccar olarak ekonomik faaliyetlere katılması, nüfus ve göç hareketleri gibi çok yönlü değerlendirme yaptığı görülmektedir. Genel yaklaşımda fiyatın doğal şartlarda devletin müdahil olmadığı Pazar şartlarında adil ve serbestçe belirlenmesi fikrini savunmaktadır. Pazara yapılacak her türlü suni müdahale ve etkilerin ekonomik hayatın sekteye uğramasına neden olabileceği uyarısında bulunmuştur.

\subsection{Emek-Değer, Ücret, Para Kuramı}

Emek-Değer Kurami: İslam iktisadı emeğe, kapitalizm sermayeye dayanır. (Tabakoğlu, 2008) $\mathrm{Bu}$ temel prensip İslam ekonomisinin vahiy ve hadis kaynaklarından beslenerek üzerinde mutabakata varılmış bir ilke olarak görülmektedir. Emek, iktisadi faaliyetlerin ve kazançların temel unsuru olarak görülmüştür. İbni Haldun da benzer şekilde insan gücü ve emeğin temel üretim faktörü olduğu tezini savunmuştur.

Emeği merkeze alan İbni Haldun, toplumların refah ve zenginliğe kavuşması için emeğin artırılması ve üretimin toplumsal iş birliği yapısıyla geliştirilmesinin önemine değinmiştir.

"Emeğin artmastyla bunun klymeti olan servet, o cemiyette çoğalır. Bunun bir sonucu olarak kazançlarının artması tabii ve zaruridir. Zenginlik o cemiyeti hayatta refaha, refahın itiyatlarından olarak evleri süslemeye, güzel giyinmeye, çanak, tabak gibi ev eşyasını güzelleştirmeye, hizmetçiler ve binek hayvanlart kullanmaya sevk eder. Bunların hepsi de edilen emeğin değerleridir." Mukaddime 2.Cilt:765 Sf.

Bu ekonomik döngü belirli iş kollarında ihtisaslaşmış ve uzmanlaşmış meslek erbaplarının oluşmasına zemin hazırlar. Çeşitlenen zanaat ve sanat kolları ile birlikte ekonomik pazarın hareketlendiği ve canlandığ görülür.

İbni Haldun'un 'Değer Teorisi' üretilen mal ve hizmetlerin değeri onun için harcanan emeğe eşittir şeklinde özetlenebilir. Emeği esas alan yaklaşımda değerin üretimde kullanılan emek ile eş değer olması klasik iktisat düşünürleri Adam Smith ve David Ricardo'nun yaklaşımı ile benzerdir. 
Ücret Yaklaşımı: Emeği temel üretim girdisi olarak gören ve değerin emek ile ölçüldüğü bir ekonomik yaklaşıma inanan İslam düşünürü ücretin de belirlenmesinde emek sahiplerine olan arz ve talep ile şehir refahı arasındaki güçlü ilişki ile modellemiştir. Gelişmiş şehirlerde ve refahın yüksek olduğu toplumlarda işçi veya emeğin karşılığı olarak ücretin yüksek olduğunu sebepleri ile açıklamıştır. Yüksek ücretin gerekçesi olarak;

- Sanayi ve ziraatın gelişmiş olduğu şehirlerde emek arzının sınırlı olması nedeniyle yüksek talep ve ihtiyaç duyulduğundan emek pahalıdır ve değeri yükselir.

- Ücretli işçi ve meslek erbapları şehrin refahı yüksek olduğu ve geçim kaygıları sınırlı olduğu için başka kimselere hizmet vermek istememektedir.

- Refah ekonomilerinde hayat süren ekonomik aktörlerin üretimde rekabet nedeniyle iş ve hizmetlerine değerinin üzerinde ücret önerilmektedir. İşçi ve zanaatkâr bulmak zor olduğu için ücretler yükselir.

İbni Haldun'un ücret kuramı harcamalar üzerine inşa edilmiştir. Ücretler arasında farklı1ıklar bulunabilir. (Abbadi, 2001) Emeğe ne kadar çok ihtiyaç duyulursa ücret o oranda yüksek olur, tersi durumda ise düşük olur. Örnek olarak ilim adamları, öğretmenler, hâkim ve liderleri vermiş, ihtiyaçlara veya harcamalarının azlığı nedeniyle daha az ücret talep ettiklerini örneklemiştir. Ücretler doğal sürecin dişında belirli şekillerde yükseklik gösterebilir.

Para Kavramı: Eserde paranın fonksiyonları ve ekonomik değerine ilişkin detaylı görüşler bulunmaktadır. Altın ve gümüşü para türleri olarak tanımlamış ve paranın mübadele aracı olarak görev icra ettiğini açıklamıştır. Paranın depolanmak, saklanmak ve değişimde kullanılmak üzere kullanılması gerektiğini ve tek başına bir değer taşımadığı kuramını ileri sürmüştür. (Ahmad R. ) Güvenilir metaller olarak pazarda kullanıldığını ve paranın ticaretin kolaylaştırılması için kullandığına dikkat çekmektedir. Malların değerinin verilen emek ve iş gücü ile ölçüldüğünü yinelemiştir.

"Yüce Allah, mal ve birikimler için klymet ölçüsü olarak altın ve gümüş denilen iki madeni taş yaratmıştır." Mukaddime 2.Cilt:807 Sf.

Altın ve gümüş eserde kıymet ölçüsü olarak değerinin korunduğu ve piyasa şartlarında kıymet kaybının diğer mallar gibi olmadığı için tedavül ettiği belirtilmiştir. Altın ve gümüşe dolayısıyla paranın fonksiyonu sadece kıymet ölçütüdür. Paranın bir emtia 
olmadığı ve değişim aracı olduğunu tanımlamıştır. Paranın iktisadi amacını açıklayan düşünür dolaylı olarak faiz yasağının esaslarına değinmiştir.

\section{4. Üretim ve Tüketim Kuramı}

İbni Haldun'un temel savını teşkil eden Umran ilmini iki esas üzerine inşa etmiştir. Eserinde Bedevi Umran ve Hazari Umran adı altında sosyal yaşamlarını anlattığı kırsal ve şehir yaşamını derinlemesine analiz etmiştir. İki ayrı toplum yapısını her yönüyle analize tabi tutarken ekonomik açıdan da ele almayı ihmal etmemiştir. Kırsal yaşamdaki hayat modeline uygun olarak toplulukların ihtiyacı kadar üretip tükettiklerini iddia etmiștir. Kırsal yaşamda geçim ve kazanç koşulları çok sınırlı olup sınırlı üretim imkânı bulunmakladır. Şehir yaşamında üretim ise çeşitlilik arz eder ve ihtiyaç duyduklarının üzerinde bir üretim veya değer ortaya koyduklarını belirtir.

Mülkiyet hakkı İbni Haldun tarafından medeni toplumun kurulması ve gelişmesinde önemli bir etken unsur olarak göz önünde tutulmuştur. Bireylerin mülkiyet hakkının olmadığı ve korunmadığı toplumlarda bireyin üretmek, ticaret yapmak ve geleceğe yönelik girişim planı yapması mümkün görülmemektedir. Birey emeği ve girişimi ile kazandığı mal ve zenginliği devletin güvencesi altında sahip olmakta ve tasarruf hakkına doğal koşullarda müdahale edilmemelidir. İbni Haldun adalet ve mülkiyet hakkı arasında doğrudan ilişkinin ve bağın bulunduğuna inanmıştır. Tacirlerin ve çiftçilerin gelirlerinin yüksek vergiler yoluyla adil olmayan bir şekilde ellerinden alınması sosyal adaletin ortadan kaybolmasını etkiler. Adaletin olmadığı her toplumda toplumsal bozulma ve ekonomik çöküş kaçınılmaz bir sondur. Toplumların zenginliği ile mülkiyet ve kazanç haklarının korunması arasında doğrudan bağ ve ilişki bulunmaktadır.

Bireysel Üretim Yaklaşımı: Mukaddimenin birinci bölümünde insanın yaratılış gayesi ve üretim ihtiyacına aşağıdaki cümle ile giriş yapar. Eserde üretimin temel girdisi insanın emeği ve kazanç çabasıdır. Üretmenin insanın yaratılış fitratının yani doğasının bir sonucu olarak var olduğunu, beşerin sahip olduğu güç ve beceri ile üretim gerçekleştirmesinin zaruretini vurgulamıştır.

"Allah insanı yaratırken gidadan başka şeyle yaşamayacak ve bekasını temin etmeyecek bir şekilde yaratmıştır. Sevk-i tabisi insana gidayı araştırmak yolunu göstermiştir. Allah insanı gidasının bulacak ve kazanabilecek kudrette yaratmıştır." Mukaddime 1.Cilt:125 Sf. 
İhtiyaç fazlası tüketimin üzerinde üretimin var olması artı değer kavramı ile tasarruf ve servet birikiminin oluşmasını da sağlamaktadır. Eserinde artı üretim veya servetin şehir hayatında gelirin artışına bağlı olarak lüks ihtiyaç ve yaşam tarzının gelişmesine imkân verdiğini ortaya koymuştur.

Toplumsal Üretim (İş Bölümü) Yaklaşımı: Modern iktisadın temel yaklaşımlarından olan iş bölümü ve uzmanlaşma Adam Smith tarafından 1776 yılında Ulusların Zenginliği eserinde bahsedilmeden asırlar önce İslam Medeniyeti düşünür ve filozofları tarafından ele alınmıştır. Mukaddime eserinde medeniyetlerin ve şehirlerin oluşumunda farklı meslek ve zanaat erbaplarının bir ahenk içerisinde üretimin ve ticaretin safhalarında rol üstlendiği belirtilmektedir. Şehir hayatının asabiyet veya yardımlaşma duygusu ile farklı görevleri paylaştıkları ve tamamlayıcı bir rol oynadıkları ifade edilmiştir.

İlk İslam Türk filozofu Farabi (870-950) El Medinet'ül Fazıla (Erdemli Devlet) eserinde Adam Smith’ten 9 asır önce aşağıdaki şekilde ifade etmiştir.

"Her insan, yaşamak ve üstün mükemmeliyetlere ulaşmak için yaradılışta birçok şeylere muhtaç olup bunların hepsini tek başına sağlayamaz. Her insan bunun için, çok kimselerin bir araya gelmesine muhtaçtır. Her fert bu ihtiyaçlardan ancak üzerine düşeni yapar. Bütün insanların birbirleri karşısındaki durumları da bu merkezdedir. Böylece her fert, tabiatında mükemmelleşme ihtiyacl, ancak muhtelif insanların- yardımlaşma maksadiyla- bir araya gelmeleriyle elde edilebilir." (Farabi, 2001)

İbni Haldun ve Adam Smith aralarında dört asırlık bir zaman dilimi olmasına karşın ekonomik kuramlarındaki benzerlikler ve paralellikler tartışma konusu olmuştur. Adam Smith "Wealth of Nations" Ulusların zenginliğini 1776 yılında yazdığında İbni Haldun'un eserinin yazılmasının (1378) üzerinden 400 y1l geçmişti. Dört asırlık bilgi ve birikimin insanlık tarihi için nedenli önemli bir zaman aralığı olduğu gözden kaçırılmaması gereken bir husustur. İş bölümü konusunda İbni Haldun'un verimli bir üretim süreci için bireylerin ihtisaslaşmak yöntemiyle iş bölümüne girmesi gerektiğine ait temel prensibi genel hatlarıyla açıklamış ve toplumların yardımlaşarak gerek hayatta kalmak gerekse üretimin verimli bir şekilde gerçekleşmesi tezini net bir şekilde ifade etmiştir. Adam Smith ise bu tezi işçi bazında ve daha detaylandırılmış örnekleme suretiyle genişletmiştir. (Ead \& Eid, 2014) Örneğin Ulusların Zenginliği kitabında işçilerin bireysel üretim kapasiteleri ile toplu üretim kapasitelerinin yardımlaşma ve ihtisaslaşmak suretiyle ne kadar fazla ilave imalat gücü ve kapasitesi getirdiği gibi detay örneklemler getirilmiştir. Batının bilimsel anlamda 
İbni Haldun'u fark etmemesi veya gözden kaçırması kadar İslami akademisyenlerin ve kültürün İbni Haldun'un ekonomik tezini dünya milletlerine yeterince anlatmaması ve tanıtmaması da ayrı bir eksiklik olarak izah edilebilir.

Mukaddimenin birinci bölümünde Allah insanı ihtiyacını ve kazancını sağlayacak bir kudret içerisinde yarattığını vurguladıktan sonra ekmek örneğini vermiştir. Örnekte ekmeğin üretimi için buğdayı eken, un haline getiren, hamuru hazırlayan ve ekmeği pişiren her birey ve bu işlemlerdeki aletleri üreten kişilerin bir ara gelmesinden bahsetmiştir. $\mathrm{Bu}$ örneği aşağıdaki cümle ile tamamlamıştır.

"Bu toplanan kimseler, birbirine yardim ederek kendilerinin sayllarından kat kat fazla insanı geçindirecek miktarda gıda maddeleri istihsal edebilirler." Mukaddime 1.Cilt:126 Sf.

Bireyin ekonomik faaliyetlerinde uzmanlaşma veya ihtisaslaşma yoluyla ekonomik aktivitelerde bulunması ekonomik değer üretmek için en verimli ve optimum ortamın varlığı anlamına gelmektedir. Uzmanlaşma, bireyin daha çok girişim cesaretinin oluşmasına ve verimli bir șekilde fayda sağlaması ile sonuçlanır. İbni Haldun, iş bölümü aynı toplum içerisindeki bireyler arasında olabileceği gibi farklı toplumlar arasında da gerçekleşebilir görüşünü ileri sürmüştür. (Falay, İbni Haldun'un İktisadi Görüşleri, 1978) $\mathrm{Bu}$ görüş milletler arasındaki ticaretin geliştirilmesi ve özendirilmesi anlamında dış ticaret fikrinin ortaya konulmasıdır.

Tüketim Kavrami: İbni Haldun'un gözlemlerinde bedevi toplumlarda kırsal yaşam şartlarının gereği olarak tüketim ve üretim arasında denge unsuru temel olarak görülmektedir. Kırsal yaşamda üretim ihtiyaç kadar yapıldığı için tüketimde aynı şekilde temel ihtiyaçları kadar tüketir. Bedevi toplumlarda yaşam yalındır ve koşullara uygun olarak yaşam gereçleri de gıda, barınma, giyim ve savunma için sağlamlık ve pratik olması aranmaktadır. (Orçan, Haziran 2010) Şehirde ise insanların ihtiyaçları farklılık arz eder ve temel ihtiyaçları dışında lüks tüketim mallarını da tercih eder. Şehir toplumunda zanaatkâr ve sanatkârların bulunması hem bu talebin hem de mesleki arzın sonucu olarak varlığını sürdürür.

Umran kuramında şehrin karmaşık yapısıyla çalıştığı, uzmanlaşma temelli üretim ve ziraat yaklaşımı ile ihtiyaçlarının üzerinde bir üretim büyüklüğüne ulaştıklarını belirtir. Üretilen fazla değer rahat yaşam veya lüks yaşam harcamalarında kullanılmak üzere diğer bölge 
insanlarına satılarak servet kazanmalarını sağlar. Şehir toplumlarında çeşitlenen ekonomik sistem beraberinde yeni ihtiyaçların doğmasını yeni ihtiyaçlar da yeni üretim ve mesleklerin doğmasına sebebiyet vererek ekonominin canlılık düzeyinin ve refahın artış etkisini artırmış olacaktır.

Kazanç Türleri: Mukaddimenin içeriğinde sosyal yapı içerisinde bireylerin kazanç veya gelir yolları izah edilmiştir. Tarım, avcılık, zanaat, ticaret ve yöneticilik kazanç türleri olarak belirtilmiştir. Yöneticilik ve devlet memurluğu da tacirlik veya üreticilik gibi ekonomik bir faaliyet kapsamında değerlendirilmiştir. Bedevi ve şehir topluluklarının farklılıklarını ve gelir türlerini ihtiyaçların ve coğrafi şartların farklılıklarına uygun olarak değişiklik gösterdiğini bölge ve şehir örnekleri ile detaylandırmıştır. (Falay, 1978) Gelişmiş toplumlarda kazanç türlerinin ve mesleklerinde sosyal refahın yüksekliğine paralel olarak çeşitlilik göstereceğine ve farklılaşacağına da farklı bölgelerdeki gelişmiş şehir örneklerine bakarak tarif etmiştir.

\section{3. İbni Haldun'dun İktisat Kuramında Devletin Ekonomi Üzerindeki Rolü ve Üstlendiği Fonksiyonları}

Mukaddime eserinde devletin ekonomik rolü konusunda örneklere ve gözlemlere dayalı objektif tespitler ve bulguları görebilirsiniz. Devleti ekonominin içerisinde ekonomik faaliyetlerde katılım pasif ve göreceli sınırlı bir ekonomik aktör olarak hedeflenmiștir. Devletin denetim ve gözetim rolü ekonominin düzen ve istikrarı için olmazsa olmaz önemli bir fonksiyon olarak vurgulanmaktadır.

İbni Haldun'un genel ekonomik dengesinin esasları güncel tabirle milli gelir artışı ve ekonomik büyüme esaslarına dayanmaktadır. Milli hasılanın artışı ve ekonomik büyümenin devletin gelişmesi ve refahının temelini teşkil etmektedir. (Choudhury, 2016) Ekonomik refahın veya toplumsal gelişmenin sağlanması için devletin mali genişlemesi, iş gücü verimliliğinin artırılması, kar marjlarının sermaye temerküzüne imkân verecek şekilde genişlemesi ve düşük vergi/gümrük tarifelerinin uygulanması başlıklarında ifade edilmiştir.

\subsection{Optimum Vergi Teorisi}


Doğru vergilendirme sistemi ekosistemin sağlıklı ve verimli çalışması için devletin üstlendiği en önemli düzenleme tekniğidir. Mukaddime 'de vergiler hem sosyal refah için devletin üstlendiği güvenlik, adalet ve eğitim gibi hizmetlerin finansmanı için gerekli hem de girişimcilerin üretim ve ticaretini engellemeyecek oran ve düzeyde belirlenmelidir. Ekonomik üretim ve katma değerin sağlanması için doğru tespiti gereken bir yasal zorunluluk olarak dengeli bir politika güdülmesi beklenen devlet rolünü ifade etmektedir. Devletin aşırı ve ağır vergiler yoluyla askeri harcamalara odaklandığı bir ekonomik sistemde reel üretimin vergi yükü ve kısıtlamalar altında üreteceği katma değer sürekli olarak daralacak ve azalma eğilimine girecektir. Artan vergi yükü baskısı girişimciliğin ve yeni yatırımların önünü keseceğinden azalan yatırımlar ve daralan ekonomik hacim beraberinde gelirlerin negatif yönde gelişimine neden olarak vergi artışı, devletin gelir artışını değil sosyal refah azalışını ve istihdam kaybını beraberinde getirecektir.

\section{"Ülkeyi imar etmenin temeli, müstahsillere imkân dahilinde az vergi yüklemektir. Bu takdirde müstahsiller üretimden istifade edeceklerine güvenirler ve severek üretimlerini artırmaya çalışırlar. Mukaddime 1.Cilt:572 $S f$.}

İbni Haldun'un vergi teorisinde aşırı ve ağır vergi yükünün ekonomik hayata zarar verdiği yaklaşımı vardır. Ağır vergilendirmenin iki açıdan ekonomik gelişmişliğe olumsuz etkisi bulunmaktadır. (Islahi, Ağustos 2015) İlki verginin yüksekliği ekonomik faaliyetlerden elde edilecek serveti azalttığı için girişimcilerin çalışma ve üretme isteğine ket vuracak şekilde etki eder. İkincisi aynı olumsuz etkinin devamı olarak kazanç sağlamayan girişimci veya üretici yeni yatırım ve tasarruf etmek noktasında isteksiz davranmasına neden olmaktadir.

Arz yanlı iktisat teorisyeni Arthur Laffer 1970'li yıllarda devletin aşırı vergi almasının iktisadi faaliyetlerde olumsuz sonuçlar doğuracağı kuramı üzerine Laffer Eğrisi olarak tanınan dünyaca ünlü vergi geliri teorisini oluşturmuştur. İbni Haldun'un Laffer 'in kuramını asırlarca önce aynı yaklaşım ile ortaya koymuş ve vergi teorisini bu açıdan ilk dile getiren düşünür olarak ifade edebiliriz. Laffer Eğrisinde vergi gelirlerinin uygun değer olduğu nokta marjinal vergi yükünün devletin gelirlerini azaltıcı etkisi belirtilmektedir. Mukaddime eserinde düşünür aynı şekilde verginin artırılması bir noktadan sonra ekonominin ana sistemine zarar verdiği için ekosistem bozulur ve vergi alınacak gelir oluşumuna mâni olur görüşündedir. 
"Vergiler derece ve yavaş yavaş arttığ için halk da, bunları toplayan da, açık olarak artış nispetini bilmez. Fakat çalışma ve istihsallerin ahaliye faydası az dokunduğu ve ümitler boşa çıktı̆̆ için, ülkenin mamurluğu etkilenir. Ahaliden birçoğu kazandiğ ile ödediği vergileri mukayese ettiğinde, çalışmasindan istifadesi az olduğu işten el çeker, imar ve üretim azlı̆̆ nispetinde vergilerden elde edilen paralar da azalır." Mukaddime 1.Cilt:572 Sf.

İbni Haldun'un vergi teorisindeki gözlemlerine dayanarak savunduğu ve vurguladığı vergi adaleti konusu teorinin önemli noktalarından birisidir. Kuzey Afrika topluluklarında yaptığı gözlemlerde idarenin mensupları arasında uyguladığı farklı ve ağırlaştırılmış vergi uygulamaları adaletsizlik duygusu ile ekonomik canlılığı olumsuz etkiler. Adaletsiz uygulamalar ticaretin ve üretimin bölgede gelişmesine engel olduğu gibi mevcut girişimcilerin terk etmesini ve teşebbüslerinin de önünde engel olarak duracaktır. Ödeme gücünün üzerinde bir vergi yükü veya belirli kesimlere muafiyet tanıma gibi toplumsal adaleti zedeleyici kararların alınmasından devlet yönetiminin kaçınması gerekmektedir. (İlgen, 2005) Vergi müteşebbisin karını ve kazancını belirleyeceği için sadece devletin gelir ve harcamalarını değil özel sektörün ve pazarın canlılığını belirleyen faktördür.

"Bir devlette halk yükletilen vergilerin miktarı az olursa, ahali çalışarak servet kazanmaya heves eder, ülke kalkınır. Vergiler azalınca üretim artar, mal ve para kazanmanın yolları çoğalır. Bir yurdun mamurluğu artar, vergileri azalırsa, o devletin hakimiyet devaml ve istikrarl olur." Mukaddime 1.Cilt:570 Sf.

Verginin mükellefler arasında adaletle dağıtılması toplumsal asabiyetin korunması açısından büyük önem arz etmektedir. Vergiler soylu, bürokrat, akraba vb. sübjektif ayrımlara tabi olmadan tüm halka adil uygulanmalı görüşü İbni Haldun tarafından vurgulanmıştır. Devletlerin çöküş döneminde israf, refah ve bolluğa alışılmasının sonucu olarak sürekli artan ihtiyaçları ve giderleri karşılamak için düzenli olarak artar. Artan giderleri için devletin ağır vergi yükü kademe kademe artar ve dayanılmaz bir hal alır. Bir nokta gelir ki vergi ödemek kazanmanın getirisin üzerinde bir külfet haline gelir. Burada tacir ve üretici ekonomik faaliyetini sürdürmek istemez.

\subsection{Kamu Maliyesi Yaklaşımı}

Mukaddime 'de uygulanan gümrük ve gelir vergilerinin devletin gelişmişlik düzeyinin ölçütlerinden birisi olarak gösterilmiştir. Devletlerin yaşam teorisine göre kuruluş, büyüme, olgunluk ve çöküş dönemlerinde kamu harcamalarının ve giderlerinin 
farklılaşmasına bağlı olarak vergilerde artış veya azalış görülmektedir. Toplumların yükseliş dönemlerinde görülen uygun ve verimli vergi politikaları durgunluk ve çöküş dönemlerinde ekonominin ve ticaretin sekteye uğramasına neden olacak yüksek ve ağır vergi uygulamalarına yerine bırakmaktadır.

İbni Haldun'a göre devletin harcamalarında aşırılık ve lüks giderlerin varlığı devletin ekonomik hayata olumsuz bir müdahalesi şeklinde tesir edecektir. Devletin lüks kamu binaları inşa etmesi kaynakların ve gelirlerin israfı anlamına gelmektedir. (Islahi, Ağustos 2015) Devletin harcamalarında verimlilik ve zorunluluk ilkesine göre hareket etmesi gerektiğini savunulmaktadır. Toplumsal refahın merkeze alındığı ekonomik felsefede zaruri olmayan ve ihtiyaç duyulmayan harcamaların kaçınılması gereken kamu harcamaları olduğu önemle vurgulanmaktadır.

İbni Haldun'un ekonomik perspektifinde devletin askeri harcamalara ayırdığı bütçenin sınırlı ve asgari düzeyde tutulması gerektiğini savunmuştur. Devlet sahip olduğu sınırlı bütçe gelirlerinin alternatif olarak toplumun gelişimi ve sosyal refahının artırılması için öncelikle toplumsal gelişim ve eğitim gibi alanlara aktarması gerektiği inancındadır. (Karataş, April 2006) Devletin sahip olduğu sınırlı vergi gelirlerinin önemli bir kısmını savunma ve askeri harcamalara aktarması asli fonksiyonlarının yerine getirilmesini engelleyecektir. Eğitim, sağlık ve sosyal güvenlik alanlarına yeterince kaynak ayrılmadığı için toplumsal refah olumsuz şekilde etkilenecektir.

Kamu harcamalarının piyasa üzerindeki doğrudan etkisi eserde detaylı olarak açıklanmıştır. Kamu harcamalarının azalmasının devletin gelirlerinde azalmaya dolaylı olarak pazarda resesyona sebebiyet vereceği açıklanmıştır. Devlet topladığı gelirleri piyasada tekrar harcayarak bireyler için gelir oluşturamazsa piyasada talep düşeceğinden arzın daralmasına bağlı olarak ekonomik durgunluğun artmasına yol açabilecektir. Eserde devlet kamu harcamaları ve kamu çalışanlarının bütçeden aldığı ücretler ile iktisadi hayatın canlılığının ve gelişmesinin birincil etkenlerinden birisi olarak görülmüştür. (Aydın, Eylül 2015) Kamu harcamalarının azalması veya ücretlerin düşmesi piyasalarda doğrudan durgunluk etkisini doğuran bir gelişmedir. Devletin harcamalarını yükseltmesi ve istikrarlı yapması doğru vergi rejiminden geçmektedir. İbni Haldun'un umran kuramının temelini oluşturan şehrin kalkınmasında devletin etkisini açıklar. Şehrin gelişmesi ve büyümesi için devletin gücüne ve organizasyonuna ihtiyaç olduğunu belirtir. Nüfus ve ticari canlılık 
ortamı sağlanan bir şehirde oluşan ekonomik gelişme beraberinde şehrin imarına katkı sağlayacak saray, cami ve kervansaray yapımına katkı sağlar. (Arslan, 1987) Şehrin imarındaki bu canlılık sanat ve ilim adamlarının şehre gelmesine ve yetişmesine uygun zemin hazırlar görüşünü ileri sürmüştür.

\section{3.İstikrarlı Mali Sistem Kuramı}

İbni Haldun mali sistemin korunması gerektiğini savunmuştur. İstikrarlı bir mali sistem için bürokratların paranın kıymetinin korunması ve değer kaybına yol açacak müdahalelerden kaçınması gerektiği görüşündedir. Devlet idarecilerinin yüksek kamu yatırımları ve askeri harcamalarının varlığı mali sistemin bozulmasına yol açacak etkenler olarak bir risk taşımaktadır. $\mathrm{Bu}$ harcamaların yüksek enflasyona neden olacağı ve enflasyonun parasal değer kaybı ile birlikte halkın milli paraya olan güvenini ortadan kaldırabileceği öngörüsünde bulunmuştur. Ekonomik yaşamda adaletli bir sistemin kurulması için parasal sistemin istikrarlı bir şekilde sürdürülmesi gerektiğine, halkın satın alma gücünün korunmasının ise bu istikrarın bir sonucu olarak doğrudan sosyal refahın düzeyini etkilediğine dikkat çekmektedir. Bu konuda istikrarın sağlanması ve mali sistemin denetimi için ise bağımsız bir kurumun kontrol görevini üstlenmesi tavsiye etmiştir. Mali sistemin korunması için özerk yapının yapılacak müdahale ve denge bozucu ekonomik kararlara karşı siyasi baskı ve kararlardan etkilenmeden adil bir karar mekanizması ile yönetmesi gerekmektedir. Parasal istikrarın korunması için merkez bankaları vasıtasıyla bağımsız bir yapı ile ekonomide mali sistemin yönetiminde aktif ve dengeliyi bir rol üstlendiği görülmektedir.

İbni Haldun'un ekonomik perspektifinde istikrarlı bir mali sistem için paranın tedavülü ve değerinin korunması temel yaklaşım olarak vurgulanmaktadır. Modern miktar teorisinin temelleri olan para arzının çokluğu veya fazlalığı ekonomik zenginliğin göstergesi olarak görülemez fikrini iddia etmiştir. Güvenilir bir paranın piyasa varlığı tüm girişimciler ve tacirler için teşvik ve yatırım iştahını artırıcı önemli bir etken olarak değerlendirilmelidir. İstikrarlı bir parasal sistem yatırım, üretim ve ticaret hacminin artması için ekosistemin kurulması ve zeminin varlığını göstermektedir. Müdahale edilen ve doğal yapısı bozulan mali sistemler ise istikrarsızlık ve güvensizliğin beraberinde getireceği ekonomik buhranların nedenleri arasında sayılabilir. 
İbni Haldun devletin piyasada oluşacak fiyatlara müdahale etmesini ve sabit fiyat belirlemesini sağlıksız bir yapıya neden olacağı görüşündedir. Toplum refahı için adil olmayan bir fiyattan malın piyasada arzını ve talebini oluşturmaya çalışmak suni bir değer oluşturacak olup doğal arz talep ilişkisinde denge fiyatına bırakılması ise en doğru ve sağlıklı piyasa fiyatlandırmasının oluşmasını sağlayacağı görüşündedir. Bu şekilde dışsal bir karar ile belirlenen fiyattan yapılan üretim ve ticaret doğal ve adil bir sistemi engellediği için zamanla üretici ve tacirler piyasadan çekilmeye ve ekonomide yer almamaya tercih etmeye başlayacaktır. Ayrıca fiyatın re'sen tespit edilmesi parasal değerin korunması dolayısıyla maliyenin de olumsuz olarak etkilenmesine yol açabilmektedir. $\mathrm{Bu}$ model ile piyasa fiyatına müdahale eden ülke ekonomilerin zamanla üretim kaybı nedeniyle dış ülkelerden ithalat ve mal transferi ile bu açı̆̆ı kapatmak zorunda kalacaklarını durumun daha da olumsuzluk etkisi getireceğini uzun vadede işaret etmektedir.

\subsection{Sınırlı (Müdahaleci Olmayan) Devlet Kuramı}

Mukaddime piyasa modelinde serbest piyasa kavramına uygun olarak mal ve hizmetlerin serbestçe dolaşımda olduğu malın fiyatının pazarda belirlendiği piyasa mekanizması kabul görmektedir. Devletin piyasa mekanizmasına ve ekonomiye müdahalesi uygun görülmemektedir. Devletin ekonomik bir aktör olarak üretim süreçlerinde ve Pazar şartlarına karışan bir fonksiyon üstlenmesini doğal ortamın bozulmasına yol açan bozucu bir faktör olarak değerlendirilmiştir. Devletin piyasalar üzerindeki rolünün murakabe şeklinde gerçekleşmesi, etik ve bozucu unsurların denetlenmesi şeklinde organize edilmesi tavsiye edilmektedir. (Tabakoğlu, 2008) Üretici veya tacir devlet yerine gözetim fonksiyonu üstlenen devlet sağlıklı bir ekonomik sistemin şartı olarak değerlendirilmektedir. Devlet ekonomik oyuncu olarak sağlayacağı avantajlar ve güç ile özel teşebbüsün veya girişimin önünü kesen rakip bir rol üstlenmesi ekonominin gelişimi ve sağlığı açısından uygun olmayan bir yaklaşım olacaktır.

Devletin ekonomik faaliyetlere doğrudan katılması sağlıklı bir ekonomik model için zafiyet oluşturabilir. Devlet memur ve bürokratlarının ekonomik faaliyetlere katılması sahip oldukları ticari veya üretim bilgileri piyasa koşulları için ve rekabet için yeterli olmadığı için gereken katma değerin üretilmesi ve ticaretin başarılı olması gereken zemin oluşmamış olacaktır. İbni Haldun'un devlet eliyle üretimin veya ekonomik faaliyetlerin yönetilmemesine ait görüşleri yakın tarihlerde birçok gelişmekte olan veya az gelişmiş 
ülkeler tarafından özelleştirme ve devletin ekonomide küçülme politikaları tercihleri ile hayata geçirilmeye başlamıştır.

"Devlet, alışverişte kar, sermaye nispetinde olduğu ve devlet adamlarının elinde de büyük servetler bulunduğu için, sermayeleri az olan tüccarları zor duruma sokarlar, mümbit topraklarda ekin ektirirler, hayvan besler ve türetirler; bu suretle kazandikları ile mas satın alır ve bu mallarl pazarlara sürerler. Bunlar bu alışverişleriyle devletin servetinin artacağl ve daha çok vergi toplayacağ iddiastyla, ticaret ve çiftçilikle meşgul olurlar. Fakat bunların bu işleri, son derece büyük bir hatadan başka bir şey değildir. Bunun birçok bakımdan halka zararı dokunur." Mukaddime 1.Cilt:576 Sf.

İbni Haldun halkın servet ve gücünün birbirine denk ve rekabet edecek düzeyde olduğunu, pazarda ticaretin ve üretimin doğal dengede işlediğini vurgular. Devlet ise büyüklüğü ve üstünlüğü ile pazarın doğal akışını bozarak piyasanın asli unsurları olan bireyleri pazarın dışına atar. Devletin sadece ticarete katılmasını değil aynı zamanda fiyatlara müdahil olmasına da bozucu etki olarak görmektedir. Rekabet edecek unsurları yok etmek amacıyla fiyatları ucuzlatmak ve pahalandırmak firsatı olduğu için ticaret erbabı ve hane halkı zamanla hem ticaret yapacak imkanları kalmaması nedeniyle hem de kazançları yetersiz olduğu için sıkıntı yaşamaya başlar, toplum refahı bozularak geçim sıkıntısı genele yayılır. Devletin ekonomi üzerindeki asli görevi sosyal refahın artırılması için gerekli yasal ortamın hazırlanması ve ekonomik aktivitelere yardımcı olacak politikaların geliştirilmesidir. Devletin ekonominin ana merkezinde olmadığı ticaretin ve üretimin asli oyuncuları olan girişimciler ve özel sektörün piyasa mekanizması içerisinde devletin temel denetim ve düzenleyici rolü içerisinde denge ve ahenk ile çalıştığ hedeflenmektedir. Devletin ekonomiye doğrudan katılması ve müdahalesi doğal aktörlerin ticari aktivitelerini olumsuz etkileyerek değer üretimini negatif yönde sonuçlandıracaktır. Üretim ve ticaret azaldıkça ekonomik canlılığın kaybolmasına neden olarak göç ve şehirlerin nüfus yoğunluğunda azalmaların sonuçları görülecektir. Devletin ekonomi üzerindeki güven sağlayıcı denetim ve düzenleme gücünü etkin bir şekilde kullanması beklenmektedir. Devlet girişimciler ve yatırıcılar için güvenilir ve istikrarlı bir ekonomik ortamın devamlılığı için etkin rol oynamalıdır. Devlet imalatın ve ticaretin artırılması için teşvik politikaları, ticari ve finans merkezlerinin kurulması, ticaret yollarının ve ulaşımın kolaylaştırılması gibi özendirici imkân ve yolların aranmasına destek vermelidir.

Mukaddime iktisadi faaliyetlerin devamı için girişimcilerin kar ve servet elde etmek isteklerinin korunması ve sürdürülmesini önemle vurgular. Kar güdüsü olmayan ekonomik 
aktiviteler değer üretmez ve geleceği sınırlı olarak ele alınmıştır. Karın olduğu yerde ticaret ve üretim gelişir, yeni yatırımların kaynağı olan sermaye birikimi ortaya çıkar. (Candan, 2007) Bu önemli iktisadi döngü için girişimcinin devlete güveni ve malının güvenliğinin de sağlanması gereklidir. Devletin haksız bir şekilde mal varlığına el koymak veya mülkiyetini zorla almak gibi mülkiyet hakkına razı göstermeyen eylemleri ekonomik aktivitelere doğrudan zarar verir ve toplumların bir arada varlığını sağlayan asabiyet veya bağlılığı ortadan kaldırır. İbni Haldun, devletin bireylerin mallarına haksız sahip olması ve düşük fiyattan satışa zorlamasını iktisadi açıdan yabancılaşma kavramı ile ifade etmektedir. (Kozak, 1984) Bireylerin ekonomideki yabancılaşması teșebbüs ve yeni girişimleri hayata geçirmesine engel olan duygudur.

\section{4. İktisadi Disiplinlerde Devletin Ekonomideki Rolü ve Tarihsel Gelişimi}

İktisadi ekollerin tamamı toplumların refahı için ideal bir ekonomik sistem modeli önermiş ve geliştirmiştir. Her iktisadi sistem aslında bir ideolojinin ekonomik cüzünü oluşturmuş ve bütün bir paradigma içerisinde yerini almıştır. Geçtiğimiz yüzyılın iki zıt yaklaşımı liberalizm ve sosyalizm temel kuramlarının içerisinde iktisadi yaklaşımlarında devleti farklı konumlandırmış ve görevler yüklemiştir. Yaşanan ekonomik kriz ve kırılmalar her defasında sistemlerin ve rollerin sorgulanması ve revizesi fikrini doğurmuştur.

Merkantilizm: Orta çağ'ın etkilerinin azaldığı 1500'lü yıllar ile 1750 sanayi devrimi dönemini kapsayan yaklaşımda devletin rolü etkin ve baskındır. Sabit ekonomik kaynakların paylaşımında altın ve gümüş stokunu artırmak suretiyle refahı hedefleyen sistemde devlet dış ticaret fazlasının oluşması için ekonomiye doğrudan müdahale etmelidir. Feodaliteden sanayi ve ticaret merkezli ekonomik düzene geçiş için devletin ticari kapitalizmi yükseltmesi ve koruması beklenmiştir. Bu yaklaşımda sermayenin temerküzü devlet eliyle sağlanmış ve korunmuştur.

Fizyokrasi: Başarısız ticari kapitalizm tecrübesi "Bırakınız yapsınlar, bırakın geçsinler" ilkesi ile özdeşleşen oluşumun başlangıcı olmuştur. Refahı ve servetin kaynağını kıymetli maden stoğu ile değil tarımsal üretimden kaynaklandığı savını ileri sürmüştür. Doğal düzen tezi ile ekonomik yaşamın kendiliğinden uyum içerisinde olacağına ve devletin bu doğal sisteme müdahalesinin gerekmediğine inanılmaktadır. Devletin harcama ve borçlanmasına 
karşı gelinmiş ve vergilerin temel değer üreten tarım gelirlerinden alınması gerektiği fikri ortaya konulmuştur.

Klasik İktisat: Sanayi devrimi ile başlayan süreçte piyasa ve fiyat mekanizması ile görünmez elin dengelediği ekonomik yaşama veya piyasaya müdahaleye gereksinim duyulmamaktadır. Rekabetin ekonomik dengenin dinamiği olarak görülen disiplinde devletin ekonomiye her türlü müdahalesi uygun görülmemiştir. Devletin güvenlik, adalet ve organizasyon görevi üstlenmesi gerektiği, piyasanın kendi dinamiğinde sağlıklı bir şekilde çalışıp toplumsal refahı üreteceği ifade edilmiştir.

Keynezyen Yaklaşım: 1929 Dünya Ekonomik Bunalımı ile birlikte klasik iktisadın görüşleri derinden sorgulanmıştır. Ekonominin kendiliğinden dengeye gelemeyeceği ve devletin müdahalesine gereksinim duyulacağı görüşünü ortaya koymuştur. Müdahaleci yaklaşım ekonominin istikrarsızlık ve bozulmalarının önüne yalnız devlet kontrol ve yönlendirilmesi ile geçileceğini, devletin ekonominin sorunlarına doğrudan ilgisinin ve katkısının olması gerektiğini açıklar. Devletin harcamaları ve bütçe planlaması ekonomin genel pozisyonu ve işleyişi için önemli bir belirleyici unsur olarak görülmektedir.

Neo-Klasik Yaklaşım: Devletin müdahaleci yaklaşımı 1970'li yıllarda devletin çözümleri yeni sorunların kaynağı olduğunu ve keynezyen politikaların krizlerin aşımında etkin olmadığı gözlemlenmiştir. Kapitalizmin revizyon ihtiyacı ve gereksinimi ile devletin ekonomideki payının küçülmesi ve piyasanın yeniden etkin kılınması gerektiğini ifade etmiştir. Minimal devlet anlayışı ile vergilerin hafifletilmesi ve devletin rolünün azaltılması temel yaklaşım olarak görülmektedir.

Arz Yanlı İktisat: 1973 Petrol krizi ile birlikte ortaya çıkan stagflasyonla ortaya çıkan olumsuz etkilerin ortadan kaldırılması için tezler üretilmiştir. Ekonomide arzın önemine odaklanan modelde vergilerin ekonomik kalkınmaya ve gelişmeye etkisi önemli vurgulanmıştır. Laffer teorisi ile vergilerin düşürülmesi ve optimum düzeyi yakalanması ekonomik refah için şarttır. (Öztürk, Mart 2006) Bu yaklaşımda devletin küçülmesi ve vergilerin düşürülmesi suretiyle girişimcilerin yatırım iştahını ve faaliyetlerinin artırarak refahın getirilmesi hedeflenmiştir. Devletin sınırlamalarının ve harcamalarının kısılması gerektiği ve müdahalelerin ortadan kaldırılmasının ekonomik gelişmenin alt yapısı olduğu görülmüştür.

Tarihsel süreçte devletin ekonomideki konumu, yaşanan iktisadi gelişmelere ve kırılmalara bağlı olarak sürekli bir değişim ve dönüşüm yaşamıştır. Devletin etkin veya aktif olmaması 
görüşleri, yaşanan toplumsal ve ekonomik olaylara göre farklılık göstermiştir. Her kriz veya bunalım beraberinde yeni çözüm arayışlarını, yeni çözümlerde yeni sorunların doğuşuna ortam hazırlamıştır. Ekoller ve disiplinlerde bir önceki veya cari uygulamanın eksikliklerini gidermek ve alternatif olmak maksadıyla ortaya çıkmıştır.

Güncel olarak olgunlaşan iktisadi yaklaşımlarda liberal iktisadi yaklaşım dünya genelinde küresel ekonomik sistemin yeni hali olmuştur. Hakim iktisadi görüş ve uygulamalarda devlet ülkelerin geri kalmış, gelişmekte veya gelişmiş olmasına göre farklı roller üstlenebilmiştir. İdeal kurguda ise devletin denetim ve düzenleyici rolünün olmazsa olmaz kabul edildiği bununla birlikte ekonomik yaşama doğrudan katılımının ve müdahalesinin daraltılması gerektiği kanaati yaygınlık kazanmıştır. Devletin toplumsal adalet ve refahının kalıcı olarak sürdürülebilmesi için yasal düzenlemenin kolaylaştırıcı ve çözümleyici olması gerekmektedir.

\section{Sonuç}

İbni Haldun'un eserinde getirdiği ekonomik çözümler ve ürettiği kuramların başarıs1 sağlam fikri altyapısının üzerinde inşa ettiği pratik tecrübe ve gözlemlerin gücünden gelmektedir. Sadece bir teorisyen olarak tahmin ve beklentiler üzerine kurulu bir yaklaşım yerine hem uygulayıcı olarak almış olduğu görevler hem de değişik bölge ve topluluklardaki gözlemleri ile kuramları gerçek olay ve toplumların tecrübesinden süzülerek gelmektedir. Dönemin çalkantılı ve bunalımların yaşandığı bir dönem olması farklı boyut ve yönlerden değerlendirme ve örnekleme fırsatını da beraberinde getirmiştir. Güçlü devlet ile sağlam bir ekonomik model arasında doğrudan bir bağ kurmuş, bu bağın iki yönlü olarak birbirlerini etkilediğini ve şekillendirdiğini ortaya koymuştur. Genel hatlarıyla Mukaddime eserinde İbni Haldun tarafından devletin ekonomide etkisi ve rolü:

- Devlet ekonomik yaşamın sağlıklı bir şekilde sürmesi için korumacı, düzenleyici ve denetleyici otorite rolünü etkin olarak üstlenmeli ve kullanmalıdır,

- Toplumsal refahın sağlanmast, yükseltilmesi ve sürdürülmesi devletin ekonomideki birincil görevidir. Ekonomik sistemin bozulmasina neden olacak etken ve tehditleri engellemek için güçlü bir savunma ve şehir yapısı kurulmalıdır.

- Adil Vergi Sistemi devletin ekonomideki ağırlı̆̆ının ve refahın sürdürülmesi için gereken gelirlerin sağlanmast için en önemli ve kritik unsurdur. 
- Devlet ekonomik faaliyetlere doğrudan katılmamall, ticaret ve üretim ile uğraşmamalıdır. Devletin doğrudan katıld $\breve{g}$ l ekonomik faaliyetleri piyasaların doğal akışını ve toplumun refahına olumsuz etkiler yapacaktır.

- Devlet harcamalarında kaynaklarını etkin bir şekilde kullanmalıdır. Gereksiz askeri harcamalar, lüks ve israfa yönelik kamu harcamalarl asli kamu harcamalarının aktarlmasinaa dolayisiyla toplum refahinin azalmasina neden olur.

- Ticaret ve üretim istikrarlı sistemlerde gelişir ve yükselir. Devlet paranın ve mali sistemin istikrarını sağlayarak kazancın ve karın kıymetini ve değerini güvence altına alır, istikrarlı pazarlar cazibe merkezi olarak çekim gücü oluşturur.

- Devletin denetim ve kontrol görevi, klasik disiplinlerden farkl olarak etik ve sosyal faydanın korunması şeklinde ahlaki ilkeler ile birlikte ele alınmalıdır. Devlet; karaborsacılık, ihtikâr, hizmet kalitesi, tüketici hakları ve firsat eşitliğinin korunması gibi toplumun refah ve adalet duygusunu güçlendirecek prensipleri getirmelidir. Sinırsız kazanç veya mutlak bireysel refahın üzerinde toplumsal refahın faydası gözetilmelidir.

İbni Haldun'un modelini kurduğu iktisadi devlet yaklaşımında, ekonomik sisteme denetleme rolü ile olumsuz sapmaları ve etkileri bertaraf edecek korumacı ve düzenleyici bir otorite yaklaşımı bulunmaktadır. Devlet ekonomik hayatta küçük ve asgari düzeyde katılımcı iken adaletli vergi sistemi ile ekonomik hayatın dengeli bir şekilde canlılığını koruyacak bir mali sistemi inşa etmelidir. Ekonomik yaşamın ve pazarın doğal akışında ve sağlıklı yürümesi için mülkiyet hakkının korunmasında, ihtikarın engellenmesi, bürokratların ticaretle meşgul olmaması ve lükse dayalı harcama bütçelerinin oluşmamasına dikkat edilmelidir. Yönetsel bozulma, ekonomik zafiyeti ekonomik yıkım da devletin çöküşünü hızlandıran bir etken olarak vurgulamıştır.

Mukaddimeyi günümüz ekonomik hayatın düzenlemesinde devletin iktisadi hayattaki konumunu ve tarifini mevcut disiplinlere bakarak 'Karma İktisadi Devlet Yaklaşımı' olarak tanımlayabiliriz. Devletin ekonomide çatı bir kurumsal yapı olarak hem nitelik hem nicelik kontrolünü ve düzenlemeleri yapan doğrudan ekonominin içinde olmayan fakat gerektiğinde veya problemler doğmadan aksiyon alarak ekonomik hayatın toplum lehine düzenlemesini sağlayarak toplumsal refahı gaye edinen bir kurgusu bulunmaktadır. 


\section{Kaynakça}

Abbadi, S. (2001). Ibn Khaldun Contribution to The Science Economics. Journal of Al Azhar University-Gaza, 41-48.

Ahmad, R. (n.d.). Ibn Khaldun- A Great Pioneer Economist. Punjab University Research in Economics.

Ahmad, Z. (2003). The Epistemology of Ibn Khaldun. London: Routledge Curzon.

Al-Leheabi, S., Bahjat, M., \& Ramchahi, A. (2013). The Economic Thought of IBN Khaldoun in His 'Muqaddimah'. World Applied Sciences Journal, 42-47.

Arslan, A. (1987). İbni Haldun'un İlim ve Fikir Dünyası. Ankara: Kültür ve Turizm Bakanlığı Yayınları.

Aydın, K. (Eylül 2015). İbni Haldun'un Toplumsal ve İktisadi Görüşleri. İstanbul: Maltepe Üniversitesi Sosyal Bilimler Enstitüsü (Yüksek Lisans Tezi).

Beik, I. S., \& Arsyianti, L. D. (2006). Ibn Khaldun's Contribution on Modern Economics Development:An Analysis based on Selected Economic Issues. International Conference on Ibn Khaldun.

Candan, N. (2007). İbni Haldun'un Gözüyle Kamu Maliyesi Yaklaşımı. Yönetim ve Ekonomi, 235-245.

Chapra, M. (2014, September). Islamic Economic Thought and The New Global Economy. Islamic Economic Studies, pp. 1-16.

Choudhury, M. (2016). Ibn Khaldun's Political Economy. İstanbul: İslam Ekonomisi ve Finansı Dergisi.

Ead, P., \& Eid, N. (2014). Between Ibn Khaldun and Adam Smith ( Fathers of Economics ). IOSR Journal of Business and Management , 54-56.

Falay, N. (1978). İbni Haldun'un İktisadi Görüşleri. İstanbul: İstanbul Üniversitesi Maliye Enstitüsü Yayın.

Falay, N. (1978). İbni Haldu'un İktisadi Görüşleri. İstanbul: Güryay Matbaac1lık.

Farabi. (2001). El Medinet'ül Fazıla. Ankara: Milli Eğitim Bakanlığı- İslam Klasikleri.

İlgen, A. (2005, Ocak). İbni Haldun'un Kamu Ekonomisi, Maliyesi ve Vergi Dünyasına İlişkin Görüş ve Analizleri. Vergi Dünyası, pp. 101-106.

Islahi, A. (Ağustos 2015). Ibn Khaldun'su Theory of Taxation and Its Relevance. Türkiye İslam İktisadı Dergisi, 1-19.

Karataş, S. C. (April 2006). The Economic Theory of Ibn Khaldun and The Rise and Fall of Nations. Foundation for Science Technology and Civilisation. 
Kayaoğlu, İ. (1980). İslami Kurumlar Tarihi. Ankara: Ankara Üniversitesi Basımevi.

Kozak, İ. E. (1984). İbni Haldun'a göre İnsan-Toplum-İktisat. İstanbul: Pınar Yayınları.

Meriç, C. (1974). Umrandan Uygarlığa. İstanbul: Ötüken Yayınevi.

Orçan, M. (Haziran 2010). Kentleşme Sürecinde Tüketim Önceliklerinde Meydana Gelen Değișme. Tüketici ve Tüketim Arafltırmaları Dergisi, 1-16.

Öztürk, N. (Mart 2006). Ekonomide Devletin Değişen Rolü. Amme İdaresi Dergisi, 17-38.

Tabakoğlu, A. (2008). İslam İktisadına Giriş. İstanbul: Dergah Yayınları.

Tekin, A. (2015). İbn Haldun Mukaddime. İstanbul: İlgi Kültür Sanat Yayıncılık.

Y1ldı, M. (2010). İbni Haldun'dun Tarihselci Devlet Kuramı. FLSF (Felsefe ve Sosyal Bilimler Dergisi), 25-55.

Ziya , H., \& Fahri, Z. (1940). İbni Haldun. İstanbul: Kanaat Kitabevi. 